\title{
РЕГИСТРАЦИОННЫЙ РЕЖИМ ЛЕГИТИМАЦИИ СУБЪЕКТОВ ПРЕДПРИНИМАТЕЛЬСТВА В РФ: ПРАВОВЫЕ ПРОБЛЕМЫ И ПУТИ СОВЕРШЕНСТВОВАНИЯ'
}

\begin{abstract}
Аннотация: В статье рассматриваются правовые проблемы действующего порядка легитимации субъектов предпринимательской деятельности в РФ, определяются основные тенденции развития законодательства о государственной регистрачии юридических лии и индивидуальных предпринимателей, анализируется правоприменительная практика в данной сфере. В работе поставлена цель сформулировать предложения, направленные на оптимизацию регистрационного режима предпринимательской деятельности в рамках улучшения условий ведения бизнеса в РФ. Исследование показало, что проиесс развития законодательства о государственной регистрации юридических лии и индивидуальных предпринимателей подвержен одновременному воздействию нескольких факторов, среди которых: реформирование гражданского законодательства, административная реформа, создание Единого экономического пространства Республики Беларусь, Республики Казахстан и Российской Федерации. Установлено, что на современном этапе особое значение имеет унификация порядка легитимачии субъектов предпринимательской деятельности в рамках законодательства государств-участников Евразийского экономического сообщества. Решение выявленных проблем правового регулирования государственной регистрации субъектов предпринимательства в РФ (неэффективность контроля за законностью создания юридических лии, невыполнение требования публичной достоверности сведений о государственной регистрации, несовершенство системы оснований отказа в государственной регистрации и т.д.) требует одновременного достижения двух противоположных иелей: усиления контроля за законностью создания таких субъектов (прежде всего, юридических лии) и дебюрократизаиии указанной процедуры. Предлагается обеспечить проверку соответствия закону учредительных документов создаваемых юридических лии, соблюдения порядка их создания и достоверности сообщаемых сведений на стадии учреждения юридических лии. Осуществление указанного контроля представляется целесообразным возложить на нотариат.

Review: The article concerns legal problems regarding the existing order of making entrepreneurial subjects legitimate in the Russian Federation. The author defines the key tendencies of legislative development on state registration of legal entities and individual entrepreneurs, and she analyzes the existing legal practice. The article aims to formulate the propositions in order to optimize the registration regime of entrepreneurial activity within the framework of improvement of business conditions in the Russian Federation. The study showed that the process of development of legislation on state registration of legal entities and individual entrepreneurs is simultaneously influenced by a number of factors, including the civil legislation reforms, administrative reform, formation of the unified economic territory with the Republic of Belarus, the Republic of Kazakhstan. It is established that currently unification of the order of making subjects of entrepreneurial activities legitimate within the legislations of the Member States of the Eurasian Economic Community (EEC). Solving the existing legal regulation problems in the sphere of state registration of entrepreneurial subjects (such as inefficient control over lawfulness of formation of legal entities, failure to provide public and authentic data on state registration, imperfections within the system of conditions for the refusal in state registration, etc.) requires simultaneous achievement of two opposite goals - strengthening control over legality of formation of such entities (mostly, organizations), and de-bureaucratizing the procedure. It is offered to guarantee the control over compliance of charter documents of newly formed legal entities, order of their formation and authenticity of the provided data at the stage of their formation, providing notary control over this sphere.
\end{abstract}


Ключевые слова: легитимация субъектов предпринимательства, государственная регистрация, создание юридических лии, условия ведения бизнеса, Евразийское экономическое сообщество, реформа гражданского законодательства, предоставление государственных услуг, достоверность данных ЕГРЮЛ, регистрирующий орган, регистрационный агент

Keywords: making entrepreneurial subjects legitimate, state registration, formation of legal entities, business conditions, EEC, reform of civil legislation, provision of state services, authenticity of the OSRLE (Official Single Register of Legal Entities), registering body, registration agent.

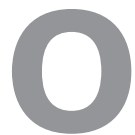

дним из основных условий осуществления предпринимательской деятельности является её легитимность (от лат. legitimus - законный, соответствующий закону или конституции), то есть государственное подтверждение законности прав и полномочий субъектов предпринимательской деятельности, их вхождения в хозяйственный оборот ${ }^{2}$. Под легитимацией субъектов предпринимательства, таким образом, понимаются правоустанавливающие процедуры, придающие законный характер предпринимательской деятельности и предоставляющие правовой статус её субъектам.

Государственная регистрация (от лат. registrum - список, перечень) в контексте рассмотрения вопроса о легитимации субъектов предпринимательства представляет собой процедуру, выполнение которой позволяет субъекту начать осуществлять предпринимательскую деятельность в определенном качестве (юридического лица, индивидуального предпринимателя) и, в то же время, предполагает возможность государства проверить законность и обоснованность соответствующего притязания.

Российское законодательство определяет процедуру государственной регистрации в качестве обязательного способа легитимации любого субъекта предпринимательской деятельности. Иные процедуры, результатом которых является приобретение субъектом права на осуществление отдельных видов предпринимательской деятельности, применяются уже после подтверждения государством статуса индивидуальных и коллективных субъектов предпринимательства и не носят универсального харак-

\footnotetext{
1 Данная статья подготовлена в рамках Программы стратегического развития ФГБОУ ВПО Московский государственный юридический университет имени О.Е. Кутафина (МГЮА); НИР «Государственное регулирование экономической деятельности в условиях членства России в ВТО, Евразийском экономическом сообществе и Таможенном союзе.», проект №2.1.1.1.
}

${ }^{2}$ См.: Ионова Ж.А. Правовые проблемы легитимации предпринимательства // Государство и право. 1997. №5. С. 46. тера, что, в свою очередь, позволяет рассматривать регистрационный режим легитимации предпринимательства ${ }^{3}$ в качестве основного.

Тем не менее, в научной литературе встречается широкое понимание легитимации субъектов предпринимательской деятельности ${ }^{4}$, включающее не только государственную регистрацию указанных субъектов, но и другие процедуры (уведомление о начале осуществления отдельных видов предпринимательской деятельности, лицензирование, аккредитацию).

С данной позицией можно поспорить, поскольку в таком случае необходимо включать в понятие легитимации субъектов предпринимательства все общие и специальные требования, которые предъявляются к началу предпринимательской деятельности, но могут вовсе не влиять на приобретение самого статуса индивидуального предпринимателя или юридического лица (например, изготовление печати, сообщение налоговому органу об открытии расчетного счёта и т. д. $)^{5}$. Указанный широкий подход представляется оправданным лишь применительно к тем процедурам, которые будут дополнительно предоставлять субъекту предпринимательской деятельности специальный правовой статус (субъекта малого и среднего предпринимательства - получателя поддержки, органа по сертификации, испытательного центра или лаборатории и т.д.).

\footnotetext{
${ }^{3}$ См.: Российское предпринимательское право: учебник / Л.В. Андреева, Т.А. Андронова, Н.Г. Апресова <и др.>; отв. ред.. И.В. Ершова, Г.Д. Отнюкова. - 4-е изд. - М.: Проспект, 2012. С. 86.

${ }^{4}$ См.: Регистрация субъектов предпринимательской деятельности: Россия и СНГ / Отв. ред. заслуженный юрист РФ, д.ю.н. Р.А. Адельханян. М. 2012. С. 32, 45-46; Тотьев К. Легитимация субъектов предпринимательской деятельности. // Законность. 2002. №12. C. 10-15.

5 Данной точки зрения придерживается, например, В.В. Тониян, которая относит постановку на учёт во внебюджетных фондах, органах статистики, изготовление печати, открытие банковского счёта к инструментам легитимации юридического лица. См.: Тониян В.В. Проблемы совершенствования законодательства о создании коммерческих организаций. М., 2006. С. 74.
} 
DOI: $10.7256 / 1811-9018.2013 .9 .9065$

При цитировании этой статьи сноска на dоі обязательна

\section{Право и политика $9(165) \cdot 2013$}

Право на свободное осуществление предпринимательской деятельности используется, прежде всего, для удовлетворения частного интереса, тем не менее, предпринимательская деятельность отдельных лиц затрагивает и общество в целом. Отсюда возникает потребность в таком механизме приобретения статуса субъекта предпринимательства, который учитывает не только частные, но и публичные интересы (возможность получения достоверной информации о субъекте предпринимательства, воспрепятствование вхождению в хозяйственный оборот недобросовестных лиц, преследующих противозаконные цели и т. д.).

Федеральный закон от 8 августа 2013 г. №129Ф3 «О государственной регистрации юридических лиц и индивидуальных предпринимателей» ${ }^{6}$ (далее - Закон о регистрации) действует уже более десяти лет, тем не менее, процесс совершенствования законодательства о государственной регистрации юридических лиц и индивидуальных предпринимателей не только не завершен, но и подвержен одновременному воздействию нескольких факторов. Характер и направления развития правового регулирования создания субъектов предпринимательства обусловлены его комплексной природой.

Прежде всего, в соответствии с Указом Президента РФ от 18 июля 2008 г. №1108 «О совершенствовании гражданского законодательства» ${ }^{7}$ осуществляется кардинальное реформирование гражданского законодательства.

В марте 2009 г. Советом при Президенте РФ по кодификации и совершенствованию гражданского законодательства была подготовлена Концепция развития законодательства о юридических лицах, в которой было, в частности, отмечено, что «...действующая система государственной регистрации юридических лиц является несовершенной по ряду ключевых позиций и не соответствует подходам, пре-

${ }^{6}$ Собрание законодательства РФ. 2001. N 33 (Часть І). Ст. 3431; 2003. N 26. Ст. 2565; 2003. N 50. Ст. 4855; 2003. N 52 (часть I). Ст. 5037; 2004. N 45. Ст. 4377; 2005. N 27. Ст. 2722; 2005. N 7 Ст. 834; 2007. N 30. Ст. 3754; 2007. N 49. Ст. 6079; 2008. N 18. Ст. 1942; 2008. N 30 (часть II). Ст. 3616; 2009. N 1. Ст. 19; 2009. N 1. Ст. 20; 2009. N 1. Ст. 23; 2009. N 29. Ст. 3642; 2009. N 52 (часть I). Ст. 6428; 2010. N 21. Ст. 2526; 2010. N 31. Ст. 4196; 2010. N 49. Ст. 6409; 2010. N 52 (часть I). Ст. 7002; 2011. N 27. Ст. 3880; 2011. N 30 (часть I). Ст. 4576; 2011. N 49 (часть V). Ст. 7061; 2012. N 14. Ст. 1553; 2012. N 31. Ст. 4322; 2012. N 53 (часть I). Ст. 7607. ${ }^{7}$ Собрание законодательства РФ. 2008. N 29 (часть I). Ст. 3482. обладающим в европейском праве» ${ }^{8}$. Большинство положений Концепции развития законодательства о юридических лицах было включено в Концепцию развития гражданского законодательства, одобренную Решением Совета при Президенте РФ по совершенствованию гражданского законодательства 7 октября 2009 г. 9.

В п.2 раздела III Концепции развития гражданского законодательства были предложены следующие принципиальные изменения процедуры государственной регистрации юридических лиц:

- установление принципа публичной достоверности Единого государственного реестра юридических лиц (далее - ЕГРЮЛ) с безусловной возможностью отказа в государственной регистрации в случае обнаружения недостоверности данных, сообщаемых в связи с государственной регистрацией юридического лица;

- установление обязательной проверки достоверности и соответствия действующему законодательству содержания учредительных документов юридического лица, а также внесения в них изменений;

- закрепление обязанности юридического лица возместить своим контрагентам убытки, если они возникли вследствие непредставления, несвоевременного представления или представления недостоверных сведений в государственный реестр юридических лиц;

- закрепление обязанности своевременного информирования заинтересованных лиц о предполагаемых изменениях учредительных документов или данных, содержащихся в государственном реестре;

- закрепление функций по регистрации всех юридических лиц и ведению ЕГРЮЛ за органами юстиции.

Реализация четырех из указанных предложений Концепции развития гражданского законодательства по изменению порядка государственной регистрации юридических лиц была связана с законопроектом N 47538-6/2 «О внесении изменений в главу 4 части первой Гражданского кодекса Российской Федерации, статью 1 Федерального закона «О несостоятельности (банкротстве)» и признании утратив-

\footnotetext{
${ }^{8}$ Портал российского частного права $<$ http://www.privlaw.ru/ vs_info2.html> (последнее посещение - 1 июля 2013 г.)

${ }^{9}$ Система ГАРАНТ.
} 
шими силу отдельных положений законодательных актов Российской Федерации» (далее - Проект о внесении изменений в гл.4 ч.1 ГК РФ).

Поскольку принятие указанного законопроекта серьезно затянулось, данные новеллы правового регулирования государственной регистрации вошли в состав другого законодательного акта Федерального закона от 28 июня 2013 г. №134-Ф3 «О внесении изменений в отдельные законодательные акты Российской Федерации в части противодействия незаконным финансовым операциям» ${ }^{10}$ (далее - Закон №134-Ф3), дополнившего п.2 ст.51 ГК РФ положениями, закрепляющими презумпцию достоверности данных ЕГРЮЛ.

Для решения проблемы информирования заинтересованных лиц о предполагаемых изменениях учредительных документов или данных, содержащихся в ЕГРЮЛ, Законом №134-Ф3 в п.4 ст.51 ГК РФ были включены положения о том, что в предусмотренных законом случаях регистрирующий орган обязан заблаговременно сообщить заинтересованным лицам о предстоящей государственной регистрации изменений устава юридического лица и о предстоящем включении данных в ЕГРЮЛ. Закон о регистрации был дополнен положением о размещении на официальном сайте регистрирующего органа в сети Интернет информации о факте представления документов в регистрирующий орган (п. 3 ст. 9).

Заинтересованные лица, в свою очередь, наделены правом направить в регистрирующий орган возражения относительно предстоящей государственной регистрации в порядке, определенном п. 6 ст. 9 Закона о регистрации. Регистрирующий орган обязан их рассмотреть и принять в порядке и в срок, определенные Законом о регистрации, соответствующее решение. Законодатель четко не определил, что подразумевается под указанным решением, однако Закон №134-ФЗ среди прочих изменений Закона о регистрации предусмотрел такое основание отказа в государственной регистрации, как получение регистрирующим органом возражения физического лица относительно предстоящего внесения данных о нём в ЕГРЮЛ (подп. «л» п.1 ст.23 Закона о регистрации).

На обеспечение достоверности сведений, содержащихся в ЕГРЮЛ, направлено новое положе-

${ }^{10}$ Собрание законодательства РФ. 2013. N 26. Ст. 3207. ние п. 3 ст. 51 ГК РФ о проверке регистрирующим органом достоверности данных, включаемых в реестр, в порядке и в срок, которые предусмотрены законом. Заметим, что механизмы осуществления регистрирующим органом указанных проверочных мероприятий Законом №134-Ф3 не проработаны. Кроме того, регистрирующий орган наделен полномочиями по отказу в государственной регистрации не во всех случаях обнаружения недостоверных данных, а только в ситуациях, предусмотренных подп. «к» и «р» п.1 ст.23 Закона о регистрации, что сужает спектр регулирующего воздействия новых положений п. 3 ст.51 ГК РФ.

В целом принятие указанных изменений оформляет тенденцию усиления контроля за созданием юридических лиц, но одновременно с положительным эффектом для стабилизации экономики, который дадут успехи в борьбе с фирмами-«однодневками», это может повлечь дополнительные неудобства и для добросовестных организаций (например, в случае недобросовестных действий граждан при направлении в регистрирующий орган возражений).

Выработка предложений, направленных на совершенствование процедур легитимации субъектов предпринимательской деятельности, ведется и в рамках предпринимательского сообщества. Так, АНО «Агентство стратегических инициатив по продвижению новых проектов» (далее - АСИ) ${ }^{11}$ подготовило в рамках Национальной предпринимательской инициативы по улучшению инвестиционного климата в Российской Федерации план мероприятий (дорожную карту) «Оптимизация процедур регистрации предприятий» ${ }^{12}$ (далее - Дорожная карта АСИ), отдельные положения которой идут вразрез с новеллами правового регулирования создания юридических лиц, предусмотренными в Проекте о внесении изменений в гл.4 ч.1 ГК РФ. В частности, наблюдается явное противоречие между предлагаемой редакцией п.4 ст. 66.2 ГК РФ о том, что учредители хозяйственного общества обязаны

\footnotetext{
${ }^{11}$ Распоряжение Правительства РФ от 11 августа 2011 г. N 1393-р «Об учреждении автономной некоммерческой организации «Агентство стратегических инициатив по продвижению новых проектов» // Собрание законодательства РФ. 2011. N 33. Ст. 4946; 2012. N 27. Ст. 3806.

${ }^{12}$ Утвержден распоряжением Правительства РФ от 7 марта 2013 г. №317-p // Собрание законодательства. 2013. N 11. Ст. 1148; 2013. N 13. Ст. 1605.
} 
DOI: $10.7256 / 1811-9018.2013 .9 .9065$

При цитировании этой статьи сноска на dоі обязательна

\section{Право и политика 9 (165) • 2013}

оплатить не менее трёх четвертей его уставного капитала до государственной регистрации общества (что ужесточает требования к формированию уставного капитала как обществ с ограниченной ответственностью, так и акционерных обществ) и предложением Дорожной карты АСИ об исключении из законодательства РФ требования о предварительной оплате уставного капитала юридических лиц .

Исходя из того, что предприниматели являются немаловажной частью общества, задачей законодателя при реформировании законодательства, регулирующего предпринимательскую деятельность, является примирение, а не противопоставление частных и публичных интересов.

В связи с этим необходимо обратить внимание на предложение о возможности юридических лиц использовать типовые уставы, утвержденные уполномоченным федеральным органом исполнительной власти, содержащееся как в Проекте о внесении изменений в гл.4 ч.1 ГК РФ (предлагаемая редакция п. 2 ст.52 ГК РФ), так и в Дорожной карте АСИ (п.2), а значит, поддерживаемое как властью, так и бизнесом. Опыт применения типовых уставов, утвержденных Министерством юстиции, имеется, например, в Испании, где применение данных положений ограничено случаями создания обществ с ограниченной ответственностью с уставным капиталом не более 3100 евро, то есть субъектов малого бизнеса ${ }^{13}$.

Одновременно процедура государственной регистрации испытывает воздействие проводимой административной реформы ${ }^{14}$. Изменение режима оказания государственных и муниципальных услуг, обусловленное принятием Федерального закона от 27 июля 2010 г. №210-Ф3 «Об организации предоставления государственных и муниципальных услуг» ${ }^{15}$, выразилось в следующих суще-

\footnotetext{
${ }^{13}$ См.: Регистрация субъектов предпринимательской деятельности: зарубежный опыт / Отв. ред. заслуженный юрист РФ, д.ю.н. Р.А. Адельханян. М., 2012. С. 143.

${ }^{14}$ См.: Концепция административной реформы в Российской Федерации в 2006-2010 годах, утв. Распоряжением Правительства РФ от 25 октября 2005 г. №1789-р // Собрание законодательства РФ. 2005. №46. Ст. 4720; 2008. N 7. Ст. 633; 2008. N 14. Ст. 1413; 2009. N 12. Ст. 1429.

${ }^{15}$ Собрание законодательства РФ. 2010. №31. Ст. 4179; 2011. N 15. Ст. 2038; 2011. N 27. Ст. 3873; 2011. N 27. Ст. 3880; 2011. N 29. Ст. 4291; 2011. N 30 (часть I). Ст. 4587; 2011. N 49 (часть V). Ст. 7061; 2012. N 31. Ст. 4322; 2013. N 14. Ст. 1651.
}

ственных новеллах процедуры государственной регистрации юридических лиц и индивидуальных предпринимателей:

- $\quad$ предусмотрена возможность представления документов в регистрирующий орган в форме электронных документов, подписанных электронной подписью;

- добавлены новые каналы представления документов для государственной регистрации, которое может осуществляться через многофункциональный центр предоставления государственных и муниципальных услуг, а также через информационно-телекоммуникационные сети общего пользования, в том числе сеть Интернет (включая единый портал государственных и муниципальных услуг);

- оптимизирован межведомственный обмен информацией и документами между регистрирующим органом и иными государственными органами, органами государственных внебюджетных фондов);

Названные изменения порядка взаимодействия заявителей при государственной регистрации юридических лиц и индивидуальных предпринимателей, регистрирующего органа и иных государственных органов, а также органов государственных внебюджетных фондов призваны не только повысить эффективность выполнения регистрирующим органом его функций, но и обеспечить большую простоту и доступность процедуры государственной регистрации для субъектов предпринимательства. Нетрудно, тем не менее, заметить, что указанные нововведения затрагивают скорее внешнюю форму легитимации предпринимателей. Сущностные же изменения данной процедуры, предложенные в рамках реформы гражданского законодательства и реализованные в Законе №134-Ф3, как было указано выше, свидетельствуют скорее об ужесточении контроля при государственной регистрации субъектов предпринимательской деятельности.

Ещё одним перспективным направлением развития правового регулирования легитимации субъектов предпринимательства является его унификация в рамках региональных организаций, участницей которых является Российская Федерация.

В основе экономической интеграции, являющейся на сегодняшний день важным фактором развития экономики России и сопредельных госу- 
дарств, лежит унификация права, которая является одним из главных её средств ${ }^{16}$. В наибольшей степени тенденция сближения правового регулирования, закрепляющего статус хозяйствующих субъектов, проявляется в документах Содружества независимых государств (далее - СНГ).

Особое место в ряду данных актов занимает Модельный Гражданский кодекс для государств - участников Содружества Независимых Государств (часть первая) от 29 октября 1994 г. ${ }^{17}$ (далее - Модельный ГК), на основе которого приняты гражданские кодексы всех стран СНГ. Не рассматривая подробно содержание данного акта, отметим, что п.2 ст.64 Модельного ГК придаёт конститутивное значение государственной регистрации для создания юридических лиц, а ст.46 определяет в качестве общего правила, отступление от которого возможно только в установленных законом случаях, возможность гражданина заниматься предпринимательской деятельностью без образования юридического лица с момента государственной регистрации в качестве индивидуального предпринимателя.

В то же время, названные документы СНГ затрагивают лишь общие вопросы государственной регистрации юридических лиц и индивидуальных предпринимателей. В научной литературе отмечается, что документа, посвященного именно единообразному регулированию регистрации юридических лиц и индивидуальных предпринимателей, на данный момент нет ${ }^{18}$. Указанное обстоятельство позволяет специалистам говорить о необходимости разработки и принятия странами СНГ международного соглашения, где были бы установлены общие требования к документам, подаваемым на государственную регистрацию юридических лиц и индивидуальных предпринимателей, к порядку подготовки, нотариального заверения и подачи документов на государственную регистрацию юридических лиц и индивидуальных предпри-

\footnotetext{
${ }^{16}$ См.: Пакерман Г.А. Унификация правового регулирования иностранных инвестиций в странах Содружества Независимых Государств. М. 2009. С. 88.

${ }^{17}$ Информационный бюллетень МПА государств - участников СНГ. 1995. №6. Приложение.

${ }^{18}$ См.: Регистрация субъектов предпринимательской деятельности: Россия и СНГ / Отв. ред. заслуженный юрист РФ, д.ю.н. Р.А. Адельханян. М. 2012. С. 220.
}

нимателей ${ }^{19}$. Не отрицая в целом данной возможности, хотелось бы заметить, что на сегодняшний день особое значение имеет унификация порядка легитимации субъектов предпринимательской деятельности в рамках законодательства государств - участников Евразийского экономического сообщества. Для Российской Федерации, Республики Беларусь и Республики Казахстан, как участниц Таможенного Союза и Единого экономического пространства, данная задача имеет первоочередной характер. Если в рамках Таможенного Союза было создано единое правовое поле в области таможенно-тарифного и нетарифного регулирования внешнеэкономической деятельности, технического регулирования, применения санитарных, ветеринарных и фитосанитарных мер, косвенного налогообложения во взаимной торговле ${ }^{20}$, то задачи создания Единого экономического пространства являются более масштабными и предполагают обеспечение эффективного функционирования общего рынка товаров, услуг, капитала и трудовых ресурсов $^{21}$. Представляется, что решение данной задачи требует определенной гармонизации и унификации законодательства Российской Федерации, Республики Беларусь и Республики Казахстан о создании юридических лиц и государственной регистрации индивидуальных предпринимателей. Так, например, в Республике Беларусь в связи с принятием Декрета Президента Республики Беларусь от 16 января 2009 г. №122 сложились весьма благоприятные условия государственной регистрации юридических лиц и индивидуальных предпринимателей, осуществляемой в день их обращения в регистрирующий орган ${ }^{23}$, что позволило Республике Беларусь в рейтинге Всемирного банка

\footnotetext{
19 Там же. С. 234.

${ }^{20}$ Интернет-интервью с директором правового Департамента Комиссии Таможенного Союза Слюсарь Н.Б. «Совершенствование институциональной основы и договорно - правовой базы Таможенного союза и Единого экономического пространства» // Система ГАРАНТ.

${ }^{21}$ Декларация о Евразийской экономической интеграции (Москва, 18 ноября 2011 г.) // Сайт Евразийской экономической комиссии $<$ http://www.tsouz.ru> (последнее посещение - 1 июля 2013 г.).

${ }^{22}$ Национальный реестр правовых актов Республики Беларусь. 2009. №17.1/10418.

23 Чигир В.Ф. Юридические лица (коммерческие и некоммерческие организации) Республики Беларусь. Минск, 2012. С. 48.
} 
DOI: 10.7256/1811-9018.2013.9.9065

При цитировании этой статьи сноска на dоі обязательна

\section{Право и политика 9 (165) • 2013}

по условиям ведения бизнеса 2012 года выйти на 9 место по условиям регистрации предприятий ${ }^{24}$.

Необходимость реформирования регистрационного режима осуществления предпринимательской деятельности в РФ действительно назрела давно. В связи с принятием в 2001 г. Закона о регистрации регистрирующий орган был лишен легальной возможности проводить правовую экспертизу представленных документов 25 , а также отказывать в государственной регистрации в случае обнаружения недостоверности представленных сведений, несоответствия представленных на государственную регистрацию документов закону или несоблюдения порядка создания юридического лица данного вида. Отказ от осуществления предварительного контроля за законностью создания юридических лиц и достоверностью сообщаемых в заявлении о государственной регистрации сведений не позволил обеспечить публичную достоверность сведений, содержащихся в ЕГРЮЛ, подрывал эффективность государственного контроля (осуществляемого регистрирующим органом, а также налогового, антимонопольного и других его видов) и создал почву для противоправных действий по отмыванию (легализации) денежных средств, полученных преступным путем, а также мошеннических действий. Результатом отказа от принципа предварительного контроля регистрирующего органа за созданием юридических лиц явилась ситуация, когда половина из юридических лиц, регистрируемых в России, создается с целью уклонения от уплаты налогов ${ }^{26}$.

Подход, реализованный в Законе о регистрации, близок к порядку создания компаний в Великобритании, где «дорегистрационная» проверка документов, представляемых для государственной регистрации юридического лица, заменена «пострегистрационной» ${ }^{27}$. Для стран романо-германской правовой системы традиционным является применение принципа предварительного контроля за

\footnotetext{
${ }^{24}$ Исследование Всемирного банка: Ведение бизнеса в 2012 году / Центр гуманитарных технологий <http://gtmarket.ru/news/state/ 2011/10/21/3682> (последнее посещение - 1 июля 2013 г.).

${ }^{25}$ См., например, письмо МНС России от 24 июня 2003 г. № ММ6-09/687@ «В дополнение к письму МНС России от 25.12.2002 № ММ-6-09/1990»// Система ГАРАНТ.

${ }^{26}$ Федеральная налоговая служба <http://www.nalog.ru/mnsrus/ statement/3781751/> (последнее посещение - 1 июля 2013 г.).

${ }^{27}$ См.: Зыкова И.В. Юридические лица: создание, реорганизация,
} ликвидация. М. 2005. С. 63. законностью создания юридических лиц, ярким примером чему является законодательство Германии и Франции. Так, в Германии до регистрации проверяется порядок учреждения акционерных обществ, содержание представленных документов (их полнота, достоверность, соответствие требованиям закона), исполнение обязанности по формированию имущественной основы общества ${ }^{28}$. При осуществлении регистрации юридических лиц во Франции суд проверяет соответствие заявления о регистрации и представленных в нём сведений установленным требованиям, а также документам, прилагаемым к указанному заявлению 29 .

Практика исполнения ФНС России Закона о регистрации свидетельствует о фактическом расширении полномочий регистрирующего органа по сравнению с перечнем полномочий, предоставляемых ему законом. Закон о регистрации устанавливает закрытый перечень оснований отказа в государственной регистрации. Однако регистрирующий орган отказывает в государственной регистрации и в случаях прямо не предусмотренных Законом о регистрации. Трактуя наличие тех или иных изъянов в представленных документах как их непредставление, регистрирующий орган выносит решение об отказе в государственной регистрации юридического лица со ссылкой на подп. а) п. 1 ст. 23 Закона о регистрации. Названная позиция ФНС России в целом поддерживается ВАС Р $\Phi^{30}$, находит определенное понимание в правовой науке ${ }^{31}$.

Тем не менее, фактическое расширение закрытого перечня оснований для отказа в государственной регистрации, установленного ст. 23 Закона о регистрации, представляется не только неоправданным, но и, более того, опасным для целей государственной регистрации юридических лиц ${ }^{32}$.

\footnotetext{
${ }^{28}$ См.: Торговое уложение Германии. Закон об акционерных обществах. Закон об обществах с ограниченной ответственностью. Закон о производственных и хозяйственных кооперативах. М. 2009. ${ }^{29}$ См.: Коммерческий кодекс Франции. М. 2008.

${ }^{30}$ См.: Определение ВАС РФ от 26 февраля 2009 г. №1690/09// Система ГАРАНТ; Постановление Президиума ВАС РФ от 8 февраля 2011 г. N 12101/10 // Вестник Высшего Арбитражного Суда РФ. 2011. N 5.

${ }^{31}$ См.: Дедов Д.И. Юридический метод: научное эссе // Система ГАРАНТ.

${ }^{32}$ См.: Трофимова Е.В. Государственная регистрация субъектов предпринимательской деятельности: цели, задачи, правовые проблемы // Бизнес и право в России и за рубежом. Приложение к журналу «Предпринимательское право». 2012. №2. С.60.
} 
Указанный перечень перестает быть, таким образом, закрытым, а основанием отказа в государственной регистрации может явиться любой порок, как содержания, так и формы представленных документов. Расширительное толкование регистрирующим органом подп. а) п. 1 ст. 23 Закона о регистрации не только делает процедуру государственной регистрации трудно преодолимой для предпринимателей, но и нарушает один из краеугольных правовых принципов - принцип законности.

Наиболее очевидным решением указанной проблемы является легальное наделение регистрирующего органа дополнительными полномочиями по осуществлению отказа в государственной регистрации. Опыт формирования перечня оснований отказа в государственной регистрации в Законе о регистрации (в том числе посредством поправок, внесенных Законом №134-ФЗ) показывает, что указанные основания должны быть сформулированы достаточно обобщенно для того, чтобы охватить все случаи, препятствующие государственной регистрации.

Во многих случаях альтернативой отказу в государственной регистрации может служить направление заявителю уведомления о необходимости устранения выявленных нарушений. В рамках указанного механизма могла бы проводиться предварительная проверка документов, представленных на государственную регистрацию, в части соблюдения требований к заполнению формы заявления и комплектности документов, предлагаемая в п.7 Дорожной карты АСИ. Это позволило бы, с одной стороны, обеспечить при осуществлении государственной регистрации чёткое соблюдение требований законодательства, a, с другой стороны, исключило бы существующую практику отказов в государственной регистрации в связи с формальными нарушениями ${ }^{33}$.

Проблема неэффективности действующего порядка государственной регистрации неоднократно поднималась в правовой науке ${ }^{34}$. За возврат к прин-

\footnotetext{
${ }^{33}$ Постановление ФАС Поволжского округа от 16 февраля 2012 г. N Ф06-343/12 по делу N A55-15517/2011 // Система ГАРАНТ.

${ }^{34}$ См.: Ломакин Д.В. О проекте федерального закона «О государственной регистрации юридических лиц» // Законодательство. 2001. № 6. С.75-79; Зыкова И.В. Правовое регулирование государственной регистрации юридических лиц: современное состояние и перспективы развития // Адвокат. 2004. № 1. С.66-77.
}

ципу предварительного контроля за созданием юридических лиц выступает и ФНС России ${ }^{35}$.

К аналогичному выводу пришли и авторы Концепции развития законодательства о юридических лицах, в п. 2 подраздела 3 разд. 1 которой предлагалось не только установить правила проверки достоверности данных, которые требуются для регистрации юридического лица, и предусмотреть возможность отказа в государственной регистрации в случае предоставления недостоверных данных, но и закрепить обязательную юридическую экспертизу содержания учредительных документов на соответствие законодательству.

В то же время, в рейтинге Всемирного банка по условиям ведения бизнеса Россия занимает на сегодняшний день только 112-е место из 185 стран, а по обеспечению стартовых условий для бизнеса находится на 101-м месте и не демонстрирует существенного прогресса по данному показателю ${ }^{36}$. В связи с указанным обстоятельством руководством страны поставлена задача осуществления комплексных и последовательных действий с целью качественного улучшения деловой среды ${ }^{37}$.

Приведенные выше предложения Концепции развития законодательства о юридических лицах (частично реализованные с принятием Закона №134Ф3) позволяют повысить эффективность государственной регистрации как инструмента контроля за законностью образования юридических лиц, однако одновременно это влечет определенное ужесточение порядка их создания, что противоречит, в свою очередь, взятому Россией курсу на улучшение условий деловой среды. Наглядным подтверждением данного тезиса является позиция Е.А. Суханова о необходимости отказа от «либерального» принципа «одного окна» и регистрации юридического лица за несколько минут в «электронной форме» и закреплении механизма юридической экспертизы учредительных

\footnotetext{
${ }_{35}$ См.: Филипенко Е.Д. Отдельные аспекты правового регулирования государственной регистрации юридических лиц в России на современном этапе // Право и экономика. 2009. №7. - C.16.

${ }^{36}$ doingbusiness.org <http://russian.doingbusiness.org/ /media/ GIAWB/Doing\%20Business/ Documents/Annual-Reports/English/DB13-full-report.pdf> (последнее посещение - 1 июля 2013 г.).

37 РосБизнесКонсалтинг < http://www.rbc.ru/rbcfreenews/ 20121024171024.shtml> (последнее посещение - 1 июля 2013 г.).
} 
DOI: $10.7256 / 1811-9018.2013 .9 .9065$

При цитировании этой статьи сноска на dоі обязательна

\section{Право и политика 9 (165) • 2013}

документов и личности учредителей, осуществляемой специализированными организациями ${ }^{38}$.

Стоит отметить, что в Законе №134-Ф3 было реализовано положение о проверке регистрирующим органом только достоверности данных, включаемых в ЕГРЮЛ (п.3 ст.51 ГК РФ), но не содержания учредительных документов на соответствие законодательству. Представляется, что для полноценной реализации указанной новеллы положения о соответствующих полномочиях регистрирующего органа, составе проверяемых сведений, механизмах и пределах осуществления указанной проверки должны быть также внесены в Закон о регистрации. Поскольку регистратор не всегда с уверенностью может утверждать, что на регистрацию представлены подложные документы, возникает необходимость проведения исследования документов, вызывающих сомнение в их подлинности, в экспертно-криминалистических центрах и лабораториях судебных экспертиз на предмет выявления фактов фальсификаций ${ }^{39}$, а это может повлечь за собой потребность в увеличении сроков осуществления государственной регистрации.

Таким образом, основной проблемой, возникающей в процессе совершенствования правового регулирования легитимации субъектов предпринимательства, выступает необходимость одновременного достижения двух противоположных целей: усиления контроля за законностью создания таких субъектов (прежде всего, юридических лиц) и дебюрократизации указанной процедуры.

В п.6 Дорожной карты АСИ содержится предложение об использовании института «регистрационных агентов» (в том числе банков и нотариусов) при государственной регистрации юридических лиц и индивидуальных предпринимателей, осуществляющих прием и дальнейшую передачу документов на государственную регистрацию в регистрирующий орган, а также удостоверение личности учредителей (участников) юридического лица или индивидуального предпринимателя с одновременным установлением в отношении «регистрационных

\footnotetext{
${ }^{38}$ Суханов Е.А. О Концепции развития законодательства о юридических лицах // Журнал российского права. 2010. №1. С.11.

${ }^{39}$ См.: Федоров А.Ю. Правовая охрана корпоративных отношений: актуальные проблемы, противодействие современным криминальным угрозам, зарубежный опыт: Научно-практическое пособие. - М. 2012. Система ГАРАНТ.
}

агентов» ответственности за предоставление в регистрирующий орган недостоверной информации, а также за непредставление или несвоевременное представление необходимых для включения в государственные реестры сведений. В целом данное предложение представляется оптимальным решением обозначенной выше проблемы, однако оно требует определенной корректировки.

Исследование опыта зарубежных стран показывает, что целесообразно рассмотреть вопрос об обеспечении проверки соответствия учредительных документов создаваемого юридического лица закону, соблюдения порядка его создания и достоверности сообщаемых сведений уже на стадии учреждения, то есть до государственной регистрации. Наиболее подходящей фигурой для осуществления указанного контроля представляется нотариус.

Так, в Италии нотариус не только готовит и удостоверяет учредительные документы обществ (меморандум и статьи ассоциации), но и проверяет формирование учредителями их уставного капитала, получение разрешений, требующихся для осуществления определенных видов деятельности, после чего направляет уведомление в официальный Реестр предпринимателей для внесения записи о регистрации общества ${ }^{40}$.

Аналогичный подход применяется в Нидерландах, где нотариусы составляют устав юридического лица, проверяют достоверность сведений, представляемых для регистрации, вносят данные сведения в торговый реестр, а также регистрируют юридическое лицо в налоговых органах ${ }^{41}$.

В Испании предусмотрено подписание акта о создании общества всеми учредителями в присутствии нотариуса. Нотариус наделен полномочиями по направлению удостоверенного им пакета документов в регистрирующий орган, а также по корректировке ошибок в регистрационных документах, обнаруженных регистратором ${ }^{42}$.

Велика роль нотариуса при осуществлении регистрации юридических лиц в прибалтийских

\footnotetext{
${ }^{40}$ См.: Регистрация субъектов предпринимательской деятельности: зарубежный опыт / Отв. ред. заслуженный юрист РФ, д.ю.н. Р.А. Адельханян. М., 2012. С. 122-124.

${ }^{41}$ Сасов К. «Липовая» регистрация юридических лиц: кому это нужно. // Консультант. 2013. №1. Система ГАРАНТ.

${ }^{42}$ См.: Регистрация субъектов предпринимательской деятельности: зарубежный опыт / Отв. ред. заслуженный юрист РФ, д.ю.н. Р.А. Адельханян. М. 2012. С. 136, 143-145.
} 
странах (Латвия, Литва, Эстония). В частности, в Литве подлинность документов юридического лица, соответствие учредительных документов требованиям законодательства, а также сам факт того, что юридическое лицо может быть зарегистрировано, заверяет нотариус ${ }^{43}$.

В России функция проверки законности создания юридического лица, также могла бы быть возложена на органы нотариата ${ }^{44}$, задачей которого является свидетельствование бесспорности юридических актов. Это позволило бы контролировать указанные параметры, не наделяя соответствующими полномочиями регистрирующий орган, что чревато ужесточением порядка государственной регистрации и, в свою очередь, ухудшением стартовых условий ведения бизнеса. В рамках реализации указанного предложения необходимо наделить нотариусов полномочиями по удостоверению учредительных документов, протоколов общих собраний (решений) учредителей (участников, акционеров), фиксирующих их волеизъявление на создание новых юридических лиц, реорганизацию и ликвидацию существующих юридических лиц, внесение изменений в их учредительные документы (сведения содержащиеся в ЕГРЮЛ). Регистрирующему органу надлежит вернуться к той роли, которую он должен был выполнять в соответствии с первоначальной редакцией Закона о регистрации - фиксировать факт возникновения новых субъектов предпринимательской деятельности, не осуществляя юридическую экспертизу представленных для государственной регистрации документов.

Усиление значения органов нотариата при представлении документов в регистрирующий орган можно отметить в качестве общей тенденции.

С момента принятия Закона о регистрации на нотариусов возложены полномочия свидетельствования подлинности подписей заявителей на заявлениях (уведомлениях, сообщениях), представляемых в регистрирующий орган.

Передача в регистрирующий орган заявления о внесении соответствующих изменений в ЕГРЮЛ нотариусом, удостоверившим сделку, направленную на отчуждение доли или части доли в уставном капитале OOO, предусмотрена также п.14 ст.21

\footnotetext{
${ }^{43}$ Там же. С. 232.

${ }^{44}$ См.: Герасимов В. Потенциал нотариата не востребован // «Рос-
} сийская юстиция». 2000. N 1. С. 31.
Федерального закона от 8 февраля 1998 г. N 14-Ф3 «Об обществах с ограниченной ответственностью» ${ }^{45}$.

Заметно возрастает значение нотариусов при представлении документов в электронной форме. Согласно Приказу ФНС России от 12 августа 2011 г. N ЯК-7-6/489@«Об утверждении Порядка направления в регистрирующий орган при государственной регистрации юридических лиц, крестьянских (фермерских) хозяйств и физических лиц в качестве индивидуальных предпринимателей электронных документов с использованием информационно-телекоммуникационных сетей общего пользования, в том числе сети Интернет, включая единый портал государственных и муниципальных услуг ${ }^{46}$ нотариус, засвидетельствовавший подлинность подписи заявителя на заявлении о регистрации, может являться (наряду с заявителем) отправителем электронных документов в регистрирующий орган.

Поскольку в указанном случае контроль за соблюдением требований к форме, содержанию и комплектности представляемых для государственной регистрации документов осуществляется нотариусом, регистрирующий орган ограничен в возможности отказа в государственной регистрации в соответствии с подп. «а» п.1 ст.23 Закона о регистрации.

Что касается возложения функций «регистрационных агентов» на банки, то данное предложение Дорожной карты АСИ выглядит не вполне удачным из-за возможного конфликта интересов банка как коммерческой организации и как субъекта, выполняющего при осуществлении проверки документов, направляемых на государственную регистрацию, публичную функцию.

Таким образом, выбор направлений совершенствования правового института государственной регистрации во многом зависит от того, какая из двух задач будет определена в качестве основной: улучшение условий деловой среды или усиление контроля за созданием субъектов предпринима-

\footnotetext{
${ }^{45}$ Собрание законодательства РФ. 1998. N 7. Ст. 785; 1998. N 28. Ст. 3261; 1999. N 1. Ст. 2; 2002. N 12. Ст. 1093; 2005. N 1 (часть I). Ст. 18; 2006. N 31 (часть I). Ст. 3437; 2006. N 52 (часть I). Ст. 5497; 2008. N 18. Ст. 1941; 2008. N 52 (часть I). Ст. 6227; 2009. N 1. Ст. 20; 2009. N 29. Ст. 3642; 2009. N 31. Ст. 3923; 2009. N 52 (часть I). Ст. 6428; 2010. N 31. Ст. 4196; 2011. N 1. Ст. 13; 2011. N 1. Ст. 21; 2011. N 29. Ст. 4291; 2011. N 30 (часть I). Ст. 4576; 2011. N 50. Ст. 7347; 2012. N 53 (часть I). Ст. 7607.

${ }^{46}$ «Российская газета» от 14 октября 2011 г. N 231.
} 
DOI: 10.7256/1811-9018.2013.9.9065

При цитировании этой статьи сноска на dоі обязательна

\section{Право и политика $9(165) \cdot 2013$}

тельства. Изменения, внесенные Законом №134-ФЗ в ст.51 ГК РФ и Закон о регистрации, свидетельствуют о приоритете второй задачи. Тем не менее, необходимость улучшения делового климата в России также не может быть снята с повестки дня. Одновременное решение указанных задач требует кардинальных изменений в подходах к государственной регистрации, чтобы контроль за созданием новых субъектов предпринимательства был действительно оптимизирован, а не ужесточен.

\section{Библиография:}

1. Герасимов В. Потенциал нотариата не востребован // “Российская юстиция”, 2000, N 1, стр. 31.

2. Дедов Д.И. Юридический метод: научное эссе. М.: Волтерс Клувер, 2008.-160 с.

3. Зыкова И.В. Правовое регулирование государственной регистрации юридических лиц: современное состояние и перспективы развития // Адвокат. 2004. № 1.-С.66-77.

4. Зыкова И.В. Юридические лица: создание, реорганизация, ликвидация. М.: Ось-89, 2005.-143 с.

5. Ионова Ж.А. Правовые проблемы легитимации предпринимательства // Государство и право. 1997. №5.-С. 46-50.

6. Ломакин Д.В. О проекте федерального закона «О государственной регистрации юридических лиц» // Законодательство. 2001. № 6.-С.75-79.

7. Пакерман Г.А. Унификация правового регулирования иностранных инвестиций в странах Содружества Независимых Государств. М.: Эксмо, 2009.-398 с.

8. Сасов К. «Липовая» регистрация юридических лиц: кому это нужно // Консультант. 2013. №1. Система ГАРАНТ.

9. Суханов Е.А. О Концепции развития законодательства о юридических лицах // Журнал российского права. 2010. №1.-С.5-12.

10. Тониян В.В. Проблемы совершенствования законодательства о создании коммерческих организаций. М.: ИД «Юриспруденция», 2006.-128 с.

11. Тотьев К. Легитимация субъектов предпринимательской деятельности // Законность. 2002. №12.-С. 10-15.

12. Трофимова Е.В. Государственная регистрация субъектов предпринимательской деятельности: цели, задачи, правовые проблемы // Бизнес и право в России и за рубежом. Приложение к журналу «Предпринимательское право». 2012. №2.-С.59-65.

13. Филипенко Е.Д. Отдельные аспекты правового регулирования государственной регистрации юридических лиц в России на современном этапе // Право и экономика. 2009. №7. - С.10-16.

14. Чигир В.Ф. Юридические лица (коммерческие и некоммерческие организации) Республики Беларусь. Минск: Амалфея, 2012.-320 с.

15. Беляева Г.С. К вопросу о классификации правовых режимов // Актуальные проблемы российского права.-2012.-2.-С. 4-10.

\section{References (transliteration):}

1. Gerasimov V. Potencial notariata ne vostrebovan // "Rossiyskaya yusticiya", 2000, N 1, str. 31.

2. Dedov D.I. Yuridicheskiy metod: nauchnoe esse. M.: Volters Kluver, 2008.-160 s.

3. Zykova I.V. Pravovoe regulirovanie gosudarstvennoy registracii yuridicheskih lic: sovremennoe sostoyanie i perspektivy razvitiya // Advokat. 2004. № 1.-S.66-77.

4. Zykova I.V. Yuridicheskie lica: sozdanie, reorganizaciya, likvidaciya. M.: Os'-89, 2005.-143 s.

5. Ionova $\mathrm{Zh} . \mathrm{A}$. Pravovye problemy legitimacii predprinimatel'stva // Gosudarstvo i pravo. 1997. №5.-S. 46-50.

6. Lomakin D.V. O proekte federal'nogo zakona «O gosudarstvennoy registracii yuridicheskih lic» // Zakonodatel'stvo. 2001. № 6.-S.75-79.

7. Pakerman G.A. Unifikaciya pravovogo regulirovaniya inostrannyh investiciy v stranah Sodruzhestva Nezavisimyh Gosudarstv. M.: Eksmo, 2009.-398 s.

8. Sasov K. «Lipovaya» registraciya yuridicheskih lic: komu eto nuzhno // Konsul’tant. 2013. №1. Sistema GARANT.

9. Suhanov E.A. O Koncepcii razvitiya zakonodatel'stva o yuridicheskih licah // Zhurnal rossiyskogo prava. 2010. №1.-S.5-12.

10. Toniyan V.V. Problemy sovershenstvovaniya zakonodatel'stva o sozdanii kommercheskih organizaciy. M.: ID «Yurisprudenciya», 2006. $-128 \mathrm{~s}$. 
DOI: 10.7256/1811-9018.2013.9.9065

При цитировании этой статьи сноска на dоі обязательна

Трансформация правовых и политических систем

11. Tot'ev K. Legitimaciya sub'ektov predprinimatel'skoy deyatel'nosti // Zakonnost'. 2002. №12. - S. 10-15.

12. Trofimova E.V. Gosudarstvennaya registraciya sub'ektov predprinimatel'skoy deyatel'nosti: celi, zadachi, pravovye problemy //Biznes i pravo v Rossii iza rubezhom. Prilozhenie k zhurnalu «Predprinimatel'skoe pravo». 2012. №2.-S.59-65.

13. Filipenko E.D. Otdel'nye aspekty pravovogo regulirovaniya gosudarstvennoy registracii yuridicheskih lic v Rossii na sovremennom etape // Pravo i ekonomika. 2009. №7.-S.10-16.

14. Chigir V.F. Yuridicheskie lica (kommercheskie i nekommercheskie organizacii) Respubliki Belarus'. Minsk: Amalfeya, 2012. - $320 \mathrm{~s}$.

15. Belyaeva G.S. K voprosu o klassifikacii pravovyh rezhimov // Aktual'nye problemy rossiyskogo prava. - 2012. - 2. - C. 4-10. 